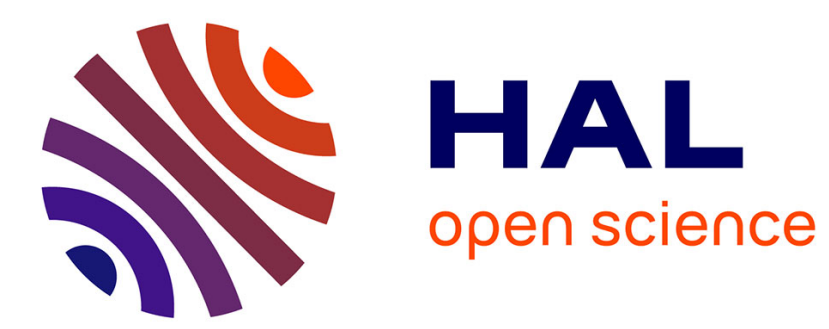

\title{
Bandwidth lost: family planners and post-war television
} Jessica Borge

\section{To cite this version:}

Jessica Borge. Bandwidth lost: family planners and post-war television. Corporate Communications: An International Journal, 2020, 25 (4), pp.655-668. 10.1108/CCIJ-11-2019-0139 . hal-03178627

\section{HAL Id: hal-03178627 https://hal.science/hal-03178627}

Submitted on 23 Mar 2021

HAL is a multi-disciplinary open access archive for the deposit and dissemination of scientific research documents, whether they are published or not. The documents may come from teaching and research institutions in France or abroad, or from public or private research centers.
L'archive ouverte pluridisciplinaire HAL, est destinée au dépôt et à la diffusion de documents scientifiques de niveau recherche, publiés ou non, émanant des établissements d'enseignement et de recherche français ou étrangers, des laboratoires publics ou privés. 


\title{
Bandwidth Lost: Family Planners and Post-War Television
}

\section{Jessica Borge,}

Post-doctoral Researcher, Département d'Histoire des sciences de la Vie et de la Santé, Université de Strasbourg, France; Visiting Fellow in Digital Humanities, School of Advanced Study, University of London, UK.

\begin{abstract}
Purpose - The purpose of this paper is to show how early planned PR efforts at the British Family Planning Association [FPA] resulted in an epoch-making television appearance in November 1955, tessellating with current methodological debates in the History of PR.
\end{abstract}

Design/methodology/approach - This paper uses a qualitative, micro-history approach, and original archival document research conducted at Wellcome Collection, London, and the BBC Written Archives Centre, Caversham, to reconstruct early PR activity at the FPA. It intercedes in debates on historiography, the diversification of the History of PR, and the concepts of mediatization and advocacy in historical contexts.

Findings - Attaining broadcast coverage for birth control issues was historically difficult, and the subject was commonly packaged into the less problematic issues of population and infertility. The FPA desired - and achieved - televisual mediatization of its organisation after establishing a focused PR plan to stage and exploit a silver jubilee event. This vindicated the FPA's mission, validated service users and created future broadcast opportunities.

Research limitations/ Implications - Research is limited by temporal scope (1870s-1950s), and reliance on document sources, footage of television programmes being unavailable. This paper has implications for the History of PR, contributing to the diversification of the field by suggesting an original approach to the intersection of public relations and social change.

Originality/value - This paper surfaces overlooked primary sources, and is the first account of how birth control appeared as a topic on early British broadcast media.

Key words: Television, Public Relations, Birth Control, Great Britain, 1950s

Paper Type: Research

\section{Acknowledgements:}

Early research for this article was undertaken under a block grant partnership from the Arts and Humanities Research Council, UK. Additional research was supported by the ERC BodyCapital project, which receives funding from the European Research Council (ERC) under the European Union's Horizon 2020 research and innovation programme.

\section{Historical Background}

The modern history of British birth control might be said to follow two core strands; the trade in commercial, for-profit, mass-produced and branded appliance contraceptives, and the progressive non-profit organization [NPO] campaigning strand, both of which emerged in the late Victorian period. The NPO birth control sector - which is the focus of this paper 
2020

- began with the Malthusian League. This was set up to promote an abstract concept of family limitation in the 1870s (Fryer, 1967; Ledbetter, 1976; Manvell, 1976). Following the opening of the first dedicated contraceptive clinic by Dr Aletta Jacobs in Amsterdam in 1882 (Drucker, 2020), Malthusian campaigners such as C.V. Drysdale agitated for similar clinics in Britain. When Marie Stopes (1880-1958), a botanist turned eugenicist and sex/birth control advocate launched the North London "Mothers' Clinic" in 1921 (and which was unconnected to the Malthusian League), other clinics followed. In 1930, voluntary clinics across Britain amalgamated as the National Birth Control Association, renamed the Family Planning Association [FPA] in 1939. Marie Stopes opted out of the FPA, and the now-dated Malthusian League continued to exist only in the shadows (Ledbetter, 1976). These organizations differed in their essential remits. The Malthusian League aimed to promote the concept of birth control without supplying contraceptives; Stopes, and her Society for Constructive Birth Control, promoted and supplied contraception on a eugenic basis; and the FPA lobbied for the mainstreaming of contraceptive practice in the context of family happiness, supplying contraceptives so that poor families could space their children.

The FPA provided quality-tested contraceptive devices via clinics on a low-cost model (Leathard, 1980), ultimately aiming for the government recognition of birth control as a social and public health necessity. But although it lobbied on this basis (Dowse and Peel, 1965; Wootton, 1975), the FPA's early planned media work and efforts to secure mass media exposure have been neglected. This paper shows that broadcast television, in particular, was of huge value to the FPA, prompting it to draw up a plan and court producers. Examination of this relationship allows us to better understand the FPA's approach to television as a publicity medium: the topic also suggests an original approach to examining the intersection of public relations and social change.

\section{Methodology}

This paper combines a qualitative, chronological approach with original archival research to examine FPA PR policy in the 1950s, with particular recourse to its silver jubilee celebrations in November 1955 and the ground-breaking television appearance that accompanied it. It intercedes in PR history in three important ways. Firstly, this paper contributes a British case study to a field dominated by American works, answering Jacquie L'Etang's call to “....research PR activities in cultures other than the USA in culturally specific and grounded ways to correct the current scholarly imbalance" (L'Etang, 2008, p.329). As will be shown, birth control stakeholders operated within a culturally specific set of limitations encompassing the history of PR, the family planning movement, and the development of broadcast television in Britain. In reconstructing events surrounding the FPA's November 1955 television appearance, this paper works within L'Etang's suggested model of PR as a type of advocacy (p. 332), again moving away from standard American models and showing how, in this instance, the services of Campbell-Johnson were offered pro bono to the FPA. The second intercession is this paper's unconventional approach in view of McKie and Xifra's assertion that “...the PR field needs to be cognizant with different approaches to historiography, to update its sources, and to adapt to associated developments in the broader historical field" (McKie and Xifra, 2014, p. 670). This paper gathers material around a core of research objects that no longer exist, namely broadcast radio and television programmes (see below). This approach also forms part of the third intervention, acting to "diversify" PR history (McKie and Xifra, 2014) by bringing in themes currently absent from the field, namely; birth control and the mediatization of the birth control movement resulting from the efforts of PR work. Mediatization has been described "...a matter of communication - how changes 
occur when communication patterns are transformed due to new communication tools and technologies, or in short: the "media"" (Lundby, 2014, p. 3). The FPA viewed television as potentially transformative, but had to learn the techniques of PR in order to harness it: this paper tells the story of that learning curve.

The first half of this paper sketches the early attempts of family planners to get onto television (sections 1-5). It then focuses on key actors, namely Marie Stopes - a notorious and outspoken family planner/author/eugenicist, the BBC, and the FPA. At the centre of this paper (sections 6-10) is a micro-history of the historic November 1955 TV appearance, which is to say a microscopic case study "concentrating on small social units consisting of concrete individuals" (Iggers, 1997, p.14). Original document research was undertaken at the archives of the FPA (Wellcome Collection, London), and BBC files and correspondence (BBC Written Archives Centre, Caversham, Reading). British television is notoriously difficult to examine because programmes made between the 1930s and 1980s were rarely recorded and cannot be re-watched (Bryant, 2010; Kavanagh et al, 2010; Wheatley, 2007). Research for this paper has found that, in combination with a lack of visual material - the 'bandwidth lost' of the title - there is a lack of clarity in the paper archive over when and where the FPA actually appeared on TV. In the early days, appearances were unplanned and scattered. Correspondence sometimes confuses the titles of TV and Radio shows (such as Woman's Hour), and at other times references TV without mentioning the programme. As such, pinpointing exactly when the FPA was broadcast has required an extra level of detective work and appearances have been identified by cross-referencing BBC Genome (an online database of historic Radio Times broadcast listings) ${ }^{1}$ with dates and times mentioned in FPA correspondence. British television had only one channel prior to 1955 (the BBC), to which the second channel (ITV) was added late that year. The third channel, BBC 2, arrived in 1964. The small number of channels makes researching TV in the 1950s easier than it might otherwise have been, but it is still necessary to triangulate sources.

So far as the BBC is concerned, only written archives are available for academic researchers to consult and no catalogue is publicly available, so research depends on the considerable knowledge of archives staff. This study has consulted papers pertaining to policy in respect of broadcasting family planning as a subject, and also files (mostly of correspondence) documenting the BBC's difficult relationship with Marie Stopes. These were kindly located for me by the archivists.

In respect of the special theme of this issue, this paper demonstrates how PR techniques were being adopted at a grassroots level just as the British PR industry was itself professionalizing (L'Etang, 2004). It is also a case study of the adoption of early PR techniques by non-corporate bodies. This is useful for understanding the pro-active agency of NPOs, and also the significant contribution of PR and PR techniques in defending and enhancing the reputation of controversial non-corporate agencies.

\section{FPA as a Birth Control Pressure Group}

Pressure group activity has a long alliance with birth control dating back to the sensational trial of Charles Bradlaugh (1833-1891) and Annie Besant (1847-1933), who were tried for obscenity in 1876 after disseminating Charles Knowlton's Fruits of Philosophy, a pamphlet on birth control. Their conviction (six months imprisonment and heavy fines) was overturned on appeal, apparently giving public advocacy of birth control the green light: The Malthusian League, the original British birth control advocacy group, was set up expressly for this purpose (Manvell, 1976). Pressure group activity - and, we might say, related activities such as PR - went hand-in-hand with the birth control movement (Dowse and Peel, 1965). Both the Malthusian League, and Marie Stopes published news-sheets 
(the New Generation and Birth Control News) promoting their own particular brands of advocacy, and Stopes was heavily invested in self-promotion, relying on the saleability of her own personal qualities to advance the cause, as she saw it. It could be said, then, that the FPA came from a line of pressure groups (Wootton, 1975).

In its supply capacity (as apart from lobbying) the FPA was instrumental in devising and implementing systematic day-to-day birth control services, for the trailing and classification of contraceptives, and for providing pregnancy testing. It also offered subfertility treatment and psychosexual counselling. FPA members cooperated with government initiatives and advised local authorities on contraceptive provision as a part of everyday health care, rooted in marriage, the family, and family values. It was a femalerun organization with a feminist agenda, focused on female methods of contraception such as diaphragms, caps and spermicides (Cook, 2004), and aimed to become the respectable public face of birth control.

\section{Exploitation of New Media}

Historically, family limitation campaigns have sought to exploit new media, including the moving image. In America, early film was beyond the purview of the restrictive Comstock laws, which curbed the dissemination of "lewd" material, and birth control pioneer Margaret Sanger (1879-1966) used it for propaganda in the 1910s and 1920s. In the 1930s attention turned to radio, then television in the 1950s (Parry, 2013). A similar timeline played out in Britain where, in 1923, Stopes's narrative feature film Maisie's Marriage created a furore among censors (Kuhn, 1986). Maisie's Marriage effectively drew attention to both Stopes and her books including the runaway success Married Love (1918), but the topic remained controversial. Broadcast radio, which was begun by the BBC in 1922, naturally lent itself as an instrument for the discussion of public interest topics. Popular science writer, philosopher, and broadcaster Julian Huxley (1887-1975) was among the first to mention it on air in 1925 and 1926, subsequently questioning where BBC policy on the subject actually stood. To Huxley, it appeared that, "though the policy of the B.B.C. may be against the raising of the question in a controversial way in debate, this does not preclude the topic from ever being mentioned over the wireless" (Huxley, 1926). In other words, the subject of birth control was limited to passing reference in the early days of broadcasting.

The Malthusian League tested this supposition by approaching the BBC with a view to making a radio program about contraception but was opposed, the BBC's position being that any such talk would have to take the form of a debate with all sides represented. The League, being used to resistance from mass media (D'Arcy, 1977) then suggested the subject be camouflaged within the less thorny issue of over-population (Controversy Committee, 1928-1929). After all, this harked back to the Reverend Thomas Malthus's (1766-1834) original concept of population 'checks' (Malthus, 1798). It was in this context that Huxley himself broached the subject (Huxley, 1926). One major problem, however, was that British population levels had reduced, posing the question of just how relevant population debates really were (Gauthier, 1993; Hall, 2000, 2013). Nonetheless, the all-encompassing population issue, despite being very much discussed for its own sake (Gauthier, 1993; Hall, 2000, 2013), provided birth control propagandists with a means of implicitly advertising their cause. The editor of New Generation, it was suggested to the BBC, might "give in an attractive form a broadcast talk on birth control". The idea was debated within the BBC's Controversy Committee which, having told The Malthusian League it would prefer to make its own arrangements for any such talks, proposed a discussion on population to appear on Talks for Women Voters, where the population question was a "burning topic of discussion" (Controversy Committee, 1928-1929). 
2020

Although not entirely adverse to the discussion of birth control, the BBC remained resistant (Teeling, 1959; Leathard, 1980). Newspapers were also cautious (Bingham, 2009).

Clothed in the population debate, coverage of birth control took off in a marginal way over the next decade. On BBC Radio 2LO [London], for example, a Mr G.D.H. Cole discussed "the diverging opinions of Malthus and Godwin in relation to Britain's modern 'Population Problem'" as part of a light entertainment schedule, in between book reviews and chamber music (Cole, 1928). By the winter of 1933-4, the letters section of The Listener was debating birth control in relation to slums, following an episode of Some British Institutions called 'A Medical Officer explains' (The Radio Times, 1933). Although the corporation was keen to avoid one-sidedness, birth control advocates ultimately benefitted from the BBC's public service remit, which decreed that all reasonable topics be considered, providing they were in the public interest. Consequently, and in lieu of direct discussions on birth control, the population question was addressed with relative regularity on BBC radio in the 1930s (Beveridge, 1932; Gauthier, 1993; Glass, 1940).

When the BBC broadcast its first regular TV programs in 1932, the FPA was only just gaining momentum as an organization, but it was a long time before television was properly exploited. This was for several reasons, not least of which was that broadcasting was limited to an hour or less per day in the 1930s, and was suspended during the Second World War. The FPA was not universally approved of, either: some regarded it as highly controversial, and Catholic opposition was strong. Coupled with this was the fact that, unlike The Malthusian League, the FPA actually sold contraceptives. If the Association was publicly discussed, this may well be construed as advertising, which - theoretically, at least - fell foul of public service remits. These "dark days of family planning" would shadow the FPA into the 1950s (Leathard, 1980).

\section{The BBC's Feud with Marie Stopes}

A further barrier to broadcast was the long-running feud between the BBC and Marie Stopes, who was unofficially embargoed, firstly on radio, and then on television. A onewoman publicity machine, Stopes was infuriated over the ban. "The B.B.C. shifts and wriggles over this question of me being allowed to broadcast, and it looks as though they are quite determined that I shall not," she wrote to one correspondent. "Of course, you know the reason, don't you?" she wrote to another. "Roman Catholic influence in the B.B.C. I am convinced, and no one strong enough outside to fight it [sic]" (BBC Ban on MCS, 1942-1943). Catholic opposition to birth control was a reality of the times, but it is likely that Stopes's personal harassment of the BBC contributed to ill feeling. She and her well wishers bombarded them with written requests for broadcasts, for meetings, and for programs featuring Stopes and her other talents, such as poetry. But although the BBC consistently maintained that there was no ban, it did not invite Stopes to speak any of her other expert subjects, which included literature, botany, and coal (BBC RCont 1, Talks, Stopes, Marie. Dr, 1930-1962; BBC Ban on MCS, 1942-1943). The feud culminated in a printed tirade in which Stopes accused the BBC of "cheap vulgarity" in its programming (Stopes, 1941), which did not help matters. Although the FPA was not affiliated with Stopes, she had claimed the mantle of the birth control cause early on and the difference between their different brands of advocacy was not obvious. A programme of targeted PR was one of the ways in which the FPA might make the difference clear. 


\section{Early PR Planning at the FPA}

It was the 1949 Royal Commission on Population that galvanized the FPA National Executive Committee into assembling a PR strategy. The Commission, through which the Royal College of Obstetricians and Gynaecologists conducted a retrospective enquiry into family limitation and human fertility (Hall, 2000, 2013), recommended that the new National Health Service [NHS] include provision for family planning services. Although the NHS was available to all and publicly financed, its creation had been politically delicate without the added complication of birth control, which, in any case, was not widely recognized as a medical issue (Peel, 1964). According to the commission, discussion around family limitation remained 'furtive', especially as the birth rate was low. Whilst the Commission's findings were discussed in the printed press, they did not make much of a splash politically. Neither the report nor its recommendations were debated in parliament, let alone implemented (Leathard, 1980). This effectively meant that contraceptive provision did not transfer to the NHS but remained with the FPA. Successive post-war governments, reported The Times of 17 July 1959, preferred to "let the situation remedy itself". ${ }^{2}$ Nonetheless, the Royal Commission's report motivated the FPA to regroup, and to look forward. This was especially important following the stagnant war years, during which the FPA had not developed its aims but simply worked to keep clinics open (Hall, 2000, 2013). The FPA was praised by the Commission (Leathard, 1980) and meant to exploit the report. Population questions continued to provided a useful inroad into the issue.

Accordingly, in March 1950, the FPA formed a publicity sub-committee and coordinated with the release of the Royal Commission's report to give a press conference. Unfortunately, this was a damp squib (PR Sub-Committee, 1950-1956). The FPA was too inexperienced to capitalize on the opportunity (Bingham, 2009) and too poor to bring in a professional PRO. The new sub-committee nevertheless aimed to impose order on the situation. At first, it was divided into two groups designed to promote the Royal Commission's report (in the hope of having it debated in parliament), and to exploit press interest in the Commission's findings. The Parliamentary Group was made up of invited MPs from all parties alongside FPA members and supporters aiming to lobby for the implementation of the Royal Commission's recommendations. The second group, designated as the Parliamentary and Public Policy Sub-Committee, focused on public policy and publicity for the Association, its object being "the spread of knowledge of the F.P.A. and general furtherance of its aims". By September of 1952, and having taken professional advice, both groups were amalgamated as the Public Relations SubCommittee (PR Sub-Committee, 1950-1956).

Few records of the sub-committee's activities exist aside from minutes, but what these show is that the aspiration of getting the Royal Commission debated in parliament failed, as did negotiations with the Minister of Health over the use of Regional Hospital Board premises for family planning clinics. The Association was told plainly that, "....if the Minister (with whom the decision would lie) decided as the F.P.A. wished, there might easily be trouble in the House of Commons, but if he decided against the F.P.A. no one would make a fuss". In 1954, and in view of the political brick wall faced by the FPA, the sub-committee elected to cease promotion of the report. Instead, the FPA would "concern itself with influencing public opinion as widely as possible" (PR Sub-Committee, 19501956). This was the "great period of expansion" for FPA clinics, with a new one opening every two weeks (Himsworth, 1976; Leathard, 1980) and the FPA put its resources into maximizing public support.

The early years of the PR Sub-Committee were spent brainstorming ideas and gradually learning what mechanisms, channels, personalities, networks and funds the FPA 
might employ to get internal PR up and running. The PR industry was itself beginning to professionalize in the 1950s (L'Etang, 2004), so it was an excellent time to learn what successful, targeted campaigning actually looked like. The FPA raised a pot of $£ 948$ towards the hire of a professional PRO, but it turned out that this was not even enough for a basic retainer. The services of a PR executive from London firm Campbell-Johnson, the FPA learned, would be upwards of $£ 1,500$ per year, with expenses on top, and would be required for at least two years to be effective. Founding director Alan Campbell-Johnson was generally reluctant to entertain ad-hoc requests from small organisations, but in the case of the FPA he loaned them, pro-bono, the services of his PA, Ruth Smith (Campbell Johnson, Correspondence 1953-1958; PR Sub-Committee, 1950-1956). Smith suggested that the FPA spend its small pot on a prestige publication. This idea later materialized as a book, The Human Sum (Rolph, 1957; PR Sub-Committee, 1950-1956; Publicity Scheme, 1954-1957). In the meantime, television was a hot topic as the nation awaited the launch of the second channel, ITV. It was with this in mind that the sub-committee consolidated its aim to influence formers of popular opinion (PR Sub-Committee, 1950-1956). Lord Simon of Wythenshawe (1879-1960), one-time chair of the BBC, former vice-president of the FPA, and international family planning advocate, topped up the PR pot with an extra $£ 500$. Ruth Smith's advice about the prestige publication notwithstanding, the FPA started to think beyond print (PR Sub-Committee, 1950-1956).

\section{The November 1955 Silver Jubilee}

The Royal Commission on Population gave the FPA impetus to pursue a course of PR. However, the sub-committee soon learned that attaching itself to non-events hoping they might generate impact was wishful thinking, and wasted resources. Media acceptance was a necessity, but opportunities for exposure didn't appear out of thin air. The way forward, then, was for to create opportunities. The FPA aimed to make birth control acceptable, and to promote itself as the public face of respectable family planning. By September 1954 it was agreed that "the fundamental object [of the publicity scheme] was prestige and to create an informed opinion in influential circles" (Publicity Scheme, 1954-1957). To this end, the committee devised a plan to manufacture a publicity event "hung on the peg" of the FPA's silver jubilee on 29 November 1955, attracting newspapers and television. A jubilee dinner would launch a yearlong "Jubilee Campaign", culminating in the publication of The Human Sum. The campaign was timed for the winter season in the hope of gaining "a better press during the Christmas recess" (PR Sub-Committee, 1950-1956).

The cherry on the cake was a public endorsement from the incumbent Minister of Health, Iain Macleod (1913-1970), who was to be the star guest. Macleod would proclaim the FPA's good work, making good copy that newspapers, with any luck, would take up. Having failed to spark debate over the Royal Commission, or to get the Ministry of Health to commit to family planning, Macleod's presence gave the FPA its first official stamp of governmental support. But although the success of the event has been attributed to Macleod's "bravery"(Leathard, 1980), which is fair comment, success was also due to careful planning, and the priming of press and television editors. A publicity plan drawn up that September was designed to attract attention from the mass media, which was thought to harbour a "conspiracy of silence" against family planning issues. The PR SubCommittee resolved to "Approach the national press systematically to break new ground" (PR Sub-Committee, 1950-1956). Margaret Pyke (1893-1966), legendary Chair of the FPA and also of the PR Sub-Committee, personally finessed Fleet Street newspaper editors into acquiescence (Bingham, 2009; PR Sub-Committee, 1950-1956). By positioning the silver jubilee in media makers' consciousness that October, Pyke secured exposure for the visit in November, with all of the attendant bells and whistles. This led to 
a flurry of local and national newspaper reporting from the Isle of Man Weekly Times to Nursery World (Macleod, Minister of Health. Visit to the FPA, 1955). Television would surely follow.

Press clippings suggest that news stories were shaped by an FPA press release, which offered a précised history of the Association, examples of the wide range of services on offer, easily repeatable factoids, and quotes from female infertility patients who were photographed bouncing children on their knees. "The crying of three babies disturbed the Minister's speech..." read Evening Standard 29 November 1955, “...the mothers of the three crying babies were former patients of the association". Press reporting was up beat, emphasizing the FPA's role in allaying marital disharmony by allowing couples to produce exactly the number of children they wanted. "We should be careful to always present a positive case", the sub-committee had agreed, "i.e. the accent should be on happy, healthy children of planned families, not on the unhappy results of lack of planning" (PR Sub-Committee, 1950-1956), a strategy that transposed easily to all of the FPA's publicity work.

Headlines such as, "Family Planning for Men. Clinic in Demand" from the Daily Telegraph on 30 November 1955, also pointed to the broader remit of the FPA in order to universalize appeal, although in truth men's services were subordinated to contraceptive sessions for women. The point, however, was to raise awareness and broaden appeal. The silver jubilee generated exactly the right type of print coverage, including a leader in the London Times, which Lord Simon called "epoch making" (PR Sub-Committee, 1950195). It was: the silver jubilee is widely acknowledged as the FPA's breakthrough moment, and historians have marked it as the point at which the Association became publicly acceptable (Hall, 2000, 2013; Kynaston, 2010). The printed press was clearly receptive to the story, but would it have been different if a professional PRO had approached them instead of Margaret Pyke? Perhaps it would have been frosty. At the time, media criticism of PR was a problem for practitioners, and journalists often tired of PROs offering gifts and hospitality in order to secure a mention (L'Etang, 2004), so the direct, grassroots approach of Pyke may have been refreshing. The question was, could print success translate to broadcast success?

\section{Television Breakthrough}

Historians have looked to the silver jubilee as the FPA's media breakthrough (Bingham, 2009; Hall, 2000, 2013; Kynaston, 2010; Leathard, 1980), but the televisual aspect of this coup has attracted scant attention. British PR history has also overlooked the importance of televisual mediatization on PR practice and the organisations it served (L'Etang, 2004). The FPA archive nonetheless tells us that the benefits of broadcast exposure were significant. In Britain, broadcast television began in 1932. The sale of television sets increased dramatically in the 1950s, especially after the coronation of Queen Elizabeth II in June 1953. The second channel, ITV (which was also the first commercial television channel), began transmission on 22 September 1955, expanding overall broadcasting hours overall (Moss, 2004). This major event doubtless influenced the PR Sub-Committee, which convened to re-vamped their publicity plan at exactly this time, hardening their resolve to get television coverage just as more people were watching. As public appetite for TV (and competition between channels) increased, the FPA decided for themselves that the time was right for this type of exposure (PR Sub-Committee, 1950-1956).

Margaret Pyke appeared twice on television for the silver jubilee, including on the BBC news program Highlight at 7.20pm on the same day as the event (PR SubCommittee, 1950-1956). Pyke's appearances were especially gratifying because the FPA, as part of a coalition with other social welfare organizations known as "The Family 
Relations Group", had been trying to get onto television since 1947, post-war television services having resumed in 1946. Back then, the request was rejected and an appeal was turned down without explanation (BBC, 1957-1968; Central Appeals Advisory Committee, 1945-1947). In December 1954, however, the FPA's work was unexpectedly mentioned on the BBC afternoon show Family Affairs in reference to infertility, resulting in 56 enquiries regarding fertility and eight about birth control. They all mention the broadcast, which, so the sub-committee felt, demonstrated impact (PR Sub-Committee, 1950-1956; BBC, 1957-1968). In March 1955, Dr Winifred May de Kok (1893-1969), a well-known women's health advocate, appeared in the BBC TV program About the Home, which also resulted in written enquiries wherein, "A number of childless wives have been put in touch with the F.P.A." (BBC \& FPA Policy, 1955).

Seeing the effect of broadcast exposure first-hand, and feeling a window of opportunity had opened, the PR Sub-Committee began badgering the producers of BBC Woman's Hour [radio] as a gateway for broadcast exposure. Unable to afford professional PROs, the FPA deployed the PR Sub-Committee, contriving to infiltrate recordings of Any Questions [radio] posing as audience members, in the hope of getting family planning questions raised. Nothing fruitful came of these efforts, however (PR Sub-Committee, 1950-1956; BBC, 1957-1968). As Huxley had intimated back in the 1920s, having guests refer to the subject on live air was one thing, but the BBC remained cautious about actively commissioning talks on the subject. It was also seemingly unaware, as would later transpire, that the FPA and Marie Stopes were unaffiliated (BBC, 1957-1968). Individual producers tried to help the FPA, but it continued to hit difficulties despite having contacts such as Lord Simon. Producer Lorna Pegram could not raise interest. "We have been trying 'up hill and down dale' to find a way round the BBC's ban on treating this subject over the air, but I am afraid that I now have to tell you that it has all been unsuccessful" she wrote (BBC \& FPA Policy, 1955). It was also pointed out to the FPA that the director of sound programming at the time was Roman Catholic, and that this might be one reason for a general embargo (PR Sub-Committee, 1950-1956).

The FPA learned that the way to get its name out was to promote services and issues peripheral to birth control, through which its contraceptive work was inferred. This much was clear from the BBC's willingness to discuss infertility, and population especially. At the time of planning the silver jubilee, the sub-committee resolved to investigate the right approach for devising "acceptable" material for television (PR Sub-Committee, 19501956). Writing to Mr Hole, Editor at the BBC News Service, Pyke invited cameras to attend on the basis of a programme of events pre-approved by the Ministry of Health. Not only did the BBC agree to bring their cameras, but they unexpectedly interviewed Pyke (BBC, 1957-1968). Pyke herself attributed this to a feature in the Observer newspaper on 27 November 1955, two days prior to the jubilee event, which printed a flattering photograph and an equally flattering description. "Mrs Pyke is a model of how to meet prejudice with clear-headed, quietly incisive argument and good-humoured tolerance", the article read (Macleod, Minister of Health. Visit to the FPA, 1955; BBC, 1957-1968). Clearly, whatever the BBC was going to get from Pyke, it would be more controlled and telegenic than the bizarre and outspoken Stopes, described recently by one journalist, with some justification, as "a turbo-Darwinist ranter" (Williams, 2011). Synchronicity on the part of Pyke and the sub-committee, combined with Pyke's quietly confident demeanour (and the absence of pushy PROs) engendered cross-media interest and cooperation at just the right moment, creating a feedback loop of television and print, all working to the FPA's benefit.

Central to the scheme was location, and the tone it set. Silver jubilee celebrations were held at the FPA's flagship clinic in North Kensington, a deprived district of West London, 
which had recently been rebranded thanks to a grant from the Eugenics Society, although the FPA never especially drew attention to this controversial funding source (Whyte, 1954). North Kensington served as the benchmark for how the FPA wished to be seen, which is to say as a social interest group with a pro-natal slant, responding to the post-war cultural preoccupation with 'family' (Kynaston, 2010). North Kensington's focus had recently shifted from woman-centred services to the promotion of married life, it's "Five Purposes" being marriage guidance, premarital health examinations, advice on birth control, infecundity [infertility], and eugenic prognosis (Constitution, 1952; Whyte, 1954). By holding the silver jubilee celebrations at this branch, the FPA signalled a progressive, forward-looking intent against a backdrop of the newly refurbished centre. Most importantly, the family focus camouflaged the topic of contraception in order to achieve the coveted mark of "acceptability" for mass media tastes. This "acceptability" was made official by the participation of the Minister of Health and the BBC.

\section{Response to Pyke's TV Appearance}

The TV appearance was unprecedented and Pyke found herself flooded with letters of congratulation. "Fancy getting T.V. as well as the press" she replied to one well-wisher. "Really, we are feeling quite dizzy here...we are swimming hard to keep abreast of the flood." In another she wrote, "It was certainly very a interesting time and we were all highly puffed up here". Interesting indeed: this had been both a learning curve and a major coup for the FPA, who were now mediatized. "The B.B.C. certainly opened its gates in a big way and now that we have risen to a "Times" leader, I feel there are no heights we may not achieve" Pyke said. "We are galloping forward so fast that we can hardly keep up". Pyke was not the only star, however, as Macleod's speech was also considered "splendid" (BBC, 1957-1968).

There is no recording of Highlights for historians to examine, but correspondence suggests that Pyke used the program to put the case of the FPA's work into family limitation, as intended, using infertility as a gateway to the birth control issue. One letter from a viewer read, "I have just listened to you on T.V. Highlights and wish to write and thank you for the work you and your staff are doing. I have benefitted from your work and have three children 9.6.3 years old, and I am happy in the assurance that I am able to limit my family while living a normal life. I am sure your work holds the answer to many world problems" (BBC, 1957-1968). Such letters were evidence of the effect of the FPA's work more generally, but also of positive reinforcement proffered by the broadcast. The fact of positive mass publicity for birth control, particularly on television, vindicated the organization's aims but also the choices made by users of the service. "I would like to congratulate you on your appearance on television this evening," another viewer wrote. "As the mother of two young children I have been very grateful for the help I have received from my local Family Planning Clinic, and have often thought your good work deserved more publicity" (BBC, 1957-1968). Branch clinics sent telegrams from across the country, realizing that this was the PR breakthrough they had been waiting for. The BBC was also full of praise, tinged, perhaps, with some relief. "Your part of the programme was certainly the most successful", Director of Talks Donald Baverstock (1924-1995) wrote to Pyke. "I was particularly pleased with your very clear and admirable treatment of a difficult subject...your appearance has provoked a considerable response from the public" (BBC, 1957-1968).

\section{After Effects}

Just as Pyke's appearance in the Observer helped along her interview on television, so the broadcast itself led to the coveted spot on Woman's Hour finally materializing the same 
day as the Times article, 1 December 1955 (BBC, 1957-1968). Vindicated, the FPA opened on-going discussions with the BBC, affirmed in the notion that "acceptability" was the key issue. For the BBC's part, it could now confirm there was no embargo on the FPA, being as how they and Stopes were clearly not part of the same organization (BBC, 19571968). In respect of any controversy arising from the broadcast, Baverstock was not especially worried, noting that letters of complaint were minimal and concerned timing rather than subject matter, with parents worried about children watching. But as Highlight was broadcast just after the 'toddler's truce' hour of 6 to $7 \mathrm{pm}$, where all TV transmission paused so that small children might be put to bed, such complaints had little sway.

Objections from Catholics were received, but Baverstock (himself an Anglican), did not see any cause for concern in these, either. Indeed, such letters could not be held representative of all Catholics, some of whom held complex views on birth control and elected to practice it (Harris, 2015). Inside the BBC, the program was "....considered a success and an important contribution" by the Highlight team. "In all," Baverstock wrote, "I suppose we had as many letters from viewers thanking us for venturing to put you on as critical ones" (BBC, 1957-1968; Moss, 2004). This was an excellent outcome for all concerned.

By November 1956, the FPA was assured there would be "...no ban on reports of our activities, and that it was up to us to devise suitable ways of getting B.B.C. publicity" (PR Sub-Committee, 1950-1956). Their successful experience equipped them for this task. In the years that followed, the FPA explored other ways to use moving images for direct lobbying, for example in the 1959 film Birthright, which was shown to 50 MPs at the House of Commons (Borge, 2019; FPA, 1960-1961). FPA PR policy aimed to inform the public about activities and services, to make its motivations known, and to "enlist and retain the support and sympathy of the public for FPA activities." But while film was useful, it dated quickly, was a 'slow' medium, and was expensive. National television coverage, on the other hand, had expanded to $95 \%$ in the 1950s. In this respect, television remained a far better (and lower cost) prospect than film and, following the jubilee, the FPA featured on at least one television or radio broadcast per year, gradually becoming the go-to media consultant for all matters to do with - and on the periphery of - British family planning.

\section{Conclusion}

As part of its advocacy remit, the FPA worked to attract the attention of broadcasters because, experience showed, even small mentions on TV yielded big responses from the public. But attaining dedicated coverage was difficult and the BBC's unofficial ban on Marie Stopes impeded efforts. This matter was cleared up at the silver jubilee, by Pyke's measured delivery in combination with the substitution of less controversial subjects such as population and infertility. Scholars in the history of contraception have rightly signalled the jubilee as one of the FPA's most significant achievements but have neglected the specific role of television, while PR historians have been unaware of the FPA's planned public relations work and its significance for PR history. This paper argues that the case of the FPA silver jubilee TV appearance, and prior efforts to win the attention of broadcasters, offer an original approach to the consideration of PR and social change not simply by bringing in the categories of gender and mediatization (thereby diversifying the field), but by complicating these categories. This paper has pushed at what McKie and Xifra have identified as a key cluster area for PR history research, namely "nation-centric mind sets, archival assumptions, and the impact of changing media" (McKie and Xifra, 2014, p. 669), because its research objects - television broadcasts - only every existed as live transmissions, as bandwidth lost to the past in the nationally specific archival context. 
McKie and Xifra suggest mediatization as a "wake-up call" for PR history because of the popularity of moving image consumption, as in the example of Ian Curtis's 2002 documentary series, Century of the Self. In one way, this is a call for PR historians to consider the shape and reach of their research outputs, but the point about popularity of surely stands as treatise for its impact in historical mediatization as well. In this sense, this paper supports their recommendation for ".... nuanced and research-relevant consideration of changing archival practices, partly stimulated by electronic curation, and the interplay between history and changing archives and archivist practices" (p. 674).

The FPA's mediatization was the intended outcome of carefully considered advance planning using the nascent techniques of PR. It became mediatized by design, through a scheme targeted to improve awareness and reputational value via modern broadcast communication channels, first radio, then television. Print journalism, as part of the news cycle, confirmed acceptability, helping broadcasters to agree to tackle the subject. Lessons learned by the PR Sub-Committee were just as valuable as the exposure itself, if not more so: the bungled example of the Royal Commission on Population showed that publicity efforts were wasted if the wrong horse was backed. Following this, adoption of the techniques and principles of PR - such as having a particular reputational goal in mind and being attractive to media makers - enabled the FPA to refine its aims and target publicity in a systematic way, with measurable outcomes. Early television appearances were an unprecedented success, increasing awareness and validating existing services and service users: one might say that the FPA were not just advocating for planned families, then, but for the adoption of planned PR.

\section{References}

Beveridge, W.H. (1932), Changes in Family Life, George Allen \& Unwin Ltd, London. Bingham, A. (2009), Family Newspapers?: Sex, Private Life, and the British Popular Press 1918-1978, Oxford University Press, Oxford and New York.

Borge, J. (2019), "According to Plan: Strategic Film Production at the London Rubber Company in the 1960s", Cahiers d'histoire du Cnam Vol. 12 No.2, pp. 73-103.

Borge, J. (2020), Protective Practices: A History of the London Rubber Company and the Condom Business, McGill-Queen's University Press, London and Montreal.

Bryant, S. (2010), "National Television Archives and Their Role", Critical Studies in Television, Vol. 5 No. 2, pp. 60-67.

Cole, G.D.H. (1928), "Modern Britain in the Making-IV, The Population Problem", Radio Times, Issue 269, p. 546.

Cook, H. (2004), The Long Sexual Revolution: English Women, Sex and Contraception 1800 - 1975, Oxford University Press, Oxford.

D’Arcy, F. (1977), "The Malthusian League and the Resistance to Birth Control Propaganda in Late Victorian Britain", Population Studies, Vol. 31 No. 3, pp. 429-448.

Dowse, R. E. and Peel, J. (1965), "The Politics of Birth Control”, Political Studies Vol.13 No.2, pp. 179-197.

Drucker, D. J. (2020), Contraception. A Concise History, MIT Press, Massachusetts. Fryer, P. (1967), The Birth Controllers, Corgi, London.

Gauthier, A. H. (1993), “Towards renewed fears of population and family decline?", European Journal of Population / Revue Européenne de Démographie, Vol. 9 No.2, pp. 143-167.

Glass, D.V. (1940), Population Policies and Movements in Europe Clarendon Press, Oxford. 
Hall, L. A. (2000, 2013), Sex, Gender and Social Change in Britain since 1880, Palgrave Macmillan, Basingstoke.

Harris, A. (2015), “The Writings of Querulous Women”: Contraception, Conscience and Clerical Authority in 1960s Britain', Recusant History Vol. 32, No. 4, pp. 55785.

Himsworth, S. J. (1976), “The Archives of the Family Planning Association. Introduction and Review", available at:

http://archives.wellcome.ac.uk/DServe/dserve.exe?dsqIni=Dserve.ini\&dsqApp= Archive \&dsqCmd=Show.tcl\&dsqDb=Catalog\&dsqPos=0\&dsqSearch=\%28Alt RefNo\%3D\%27SA/FPA\%27\%29 (accessed 18 June 2020).

Huxley, J. S. (1926), "Broadcasting Birth Control”, correspondence, Nature Vol. 118 No. 2978 , p. 771.

Iggers, G. G. (1997, 2005), Historiography in the Twentieth Century: From Scientific Objectivity to the Postmodern Challenge, Wesleyan University Press, Middletown, Connecticut.

Kavanagh, J. and Lee, A. (2010), “Accessing TV History: Accessing BBC Archives”, Critical Studies in Television, Vol. 5 No. 2, pp. 68-72.

Kuhn, A. (1986), “The 'Married Love Affair”, Screen, Vol. 27 No. 2, pp. 5-21.

Kynaston, D, (2010), Family Britain, 1951-1957 (Tales of a New Jerusalem), Bloomsbury, London.

L'Etang, J. (2004), Public Relations in Britain. A History of Professional Practice in the 20th Century, Lawrence Erlbaum Associates, New Jersey.

L'Etang, J. (2008), "Writing PR history: issues, methods and politics", Journal of Communication Management, Vol. 12 No. 4, pp. 319-355.

Leathard, A. (1980), The Fight for Family Planning: The Development of Family Planning Services in Britain 1921-1974, Macmillan Press, London.

Ledbetter, R. (1976), A History of the Malthusian League, Ohio State University Press, Columbus, $\mathrm{OH}$.

Lundby, K. (Ed) (2014), Mediatization of Communication, Vol. 21, De Gruyter Inc., Berlin.

McKie, D. and Xifra, J. (2014), "Resourcing the next stages in PR history research: The case for historiography", Public Relations Review, Vol. 40, pp. 669-675.

Malthus, T. (1798), An Essay on the Principles of Population, London, J Johnson.

Manvell, R. (1976), The Trial of Annie Besant and Charles Bradlaugh, Elek, London.

Marks, L. V. (2001), Sexual Chemistry: A History of the Contraceptive Pill, Yale University Press, New Haven and London,.

Moss, N. (2004), "Baverstock, Donald Leighton (1924-1995)", Oxford Dictionary of National Biography, 23 September 2004, available at: https://www.oxforddnb.com/view/10.1093/ref:odnb/9780198614128.001.0001/o dnb-9780198614128-e-59713?rskey=ISyJXJ (accessed 18 June 2020).

Nelson, R., and Cooke, L. (2010), Television Archives: Accessing TV History, SAGE Publications, London.

Parry, M. (2013), Broadcasting Birth Control, Rutgers University Press, New Brunswick, N.J.

Peel, J. (1964), “Contraception and the Medical Profession”, Population Studies, Vol. 18 No. 2, pp. 133-134.

Pyke, M. (1956), "Pimlico to Knightsbridge", Family Planning, Vol. 4 No. 4, pp. 3-5.

Radio Times (1933), "Wednesday”, 10 November, 432.

Rolph, C.H., (1957), The Human Sum, Heinemann, London. 
Stopes, M.C. (1918), Married Love or Love in Marriage, The Critic and Guide Company, New York and London.

Wheatley, H. (2007), Re-Viewing Television History: Critical Issues in Television Historiography, I.B. Tauris, London.

Whyte, G.A. (1954), “The Eugenics Society”, Eugenics Review Vol. 46 No. 1, pp. 17-19.

Williams, Z. (2011), "Marie Stopes: a turbo-Darwinist ranter but right about birth control", The Guardian, 2 September 2011, available at: https://www.theguardian.com/theguardian/2011/sep/02/marie-stopesright-birth-control (accessed 18 June 2020).

Wootton, G. (1975), Pressure Groups in Britain 1720-1970, Allen Lane, London.

\section{Archival Sources}

BBC \& FPA Policy, (1955), unpublished Papers (John Peel Papers and History

Collection), Family Planning Association Archive, FPA/A23/55/50/1H,

Wellcome Collection, London.

BBC Ban on MCS, Correspondence (1942-1943), unpublished correspondence, Marie

Carmichael Stopes Personal Papers, PP/MCS/E/16:Box 62, Wellcome

Collection, London.

BBC, 1957-1968, unpublished papers (Television and Radio), Family Planning

Association Archive, FPA/A17/39-42, Wellcome Collection, London.

BBC RCont 1 Talks, Stopes, Marie. Dr, (1930-1962), unpublished papers, File I, BBC

Written Archives Centre, Caversham.

Campbell Johnson, Correspondence 1953-1958, Unpublished Papers, Family Planning Association Papers, FPA/A17/10, Wellcome Collection, London.

Central Appeals Advisory Committee, (1945-1947), Unpublished Minutes, R7/18/5, BBC Written Archives Centre, Caversham.

Controversy Committee (1928-1929), unpublished minutes, BBC WA R34/318, BBC Written Archives Centre, Caversham.

Constitution, (1952), unpublished papers, North Kensington Marriage Welfare Centre, Family Planning Association Papers, FPA/NK/5A, Wellcome Collection, London.

Correspondence with branches and BBC, (1954-1964), unpublished papers, Family Planning Association Archive, FPA/A17/5, Wellcome Collection, London.

Macleod, Minister of Health. Visit to the FPA, (1955), unpublished papers, Family Planning Association Archive, FPA/A17/92, Wellcome Collection, London.

PR Sub-Committee, (1950-1956), unpublished minutes (Committees and Councils), Family Planning Association Archive, FPA/A5/45, Wellcome Collection, London.

Publicity Scheme, (1954-1957), unpublished papers (Publicity, General Correspondence and Papers), Family Planning Association Archive, FPA/A17/2.

Stopes, M. (1941), Newsletter. Available in BBC RCont 1 Talks, Stopes, Marie. Dr, (1930-1962), unpublished papers, File I, BBC Written Archives Centre, Caversham.

Teeling, L. (1959), "The Week's Good Cause", (Appeals), House of Commons Deb, 01 July, Vol. 608, col 452. Historic Hansard.

[1] BBC Genome available at: https://genome.ch.bbc.co.uk 
[2] National, state-sponsored family planning services would not be rolled out until the 1974 NHS reorganization, when the NHS began the gradual takeover of FPA clinics. 